Témoigner Témoigner. Entre histoire et mémoire

Getuigen Revue pluridisciplinaire de la Fondation Auschwitz

$126 \mid 2018$

Questions sur l'avenir du travail de mémoire

\title{
"It Was Not Hundreds of Thousands, but One, Plus One, Plus One"
}

Emotions and Empathy in History Learning with Virtual Shoah Survivors

\section{Katalin Morgan}

\section{(2) OpenEdition}

\section{Journals}

\section{Édition électronique}

URL : https://journals.openedition.org/temoigner/7412

DOI : $10.4000 /$ temoigner.7412

ISSN : 2506-6390

Éditeur :

Éditions du Centre d'études et de documentation Mémoire d'Auschwitz, Éditions Kimé

Édition imprimée

Date de publication : 2 avril 2018

Pagination : 128-137

ISBN : 978-2-930953-06-9

ISSN : 2031-4183

\section{Référence électronique}

Katalin Morgan, "It Was Not Hundreds of Thousands, but One, Plus One, Plus One" », Témoigner. Entre histoire et mémoire [En ligne], 126 | 2018, mis en ligne le 24 janvier 2022, consulté le 04 février 2022 URL : http://journals.openedition.org/temoigner/7412; DOI : https://doi.org/10.4000/temoigner.7412 


\section{"It Was Not Hundreds of Thousands, but One, Plus One, Plus One."}

\section{Emotions and Empathy in History Learning with Virtual Shoah Survivors}

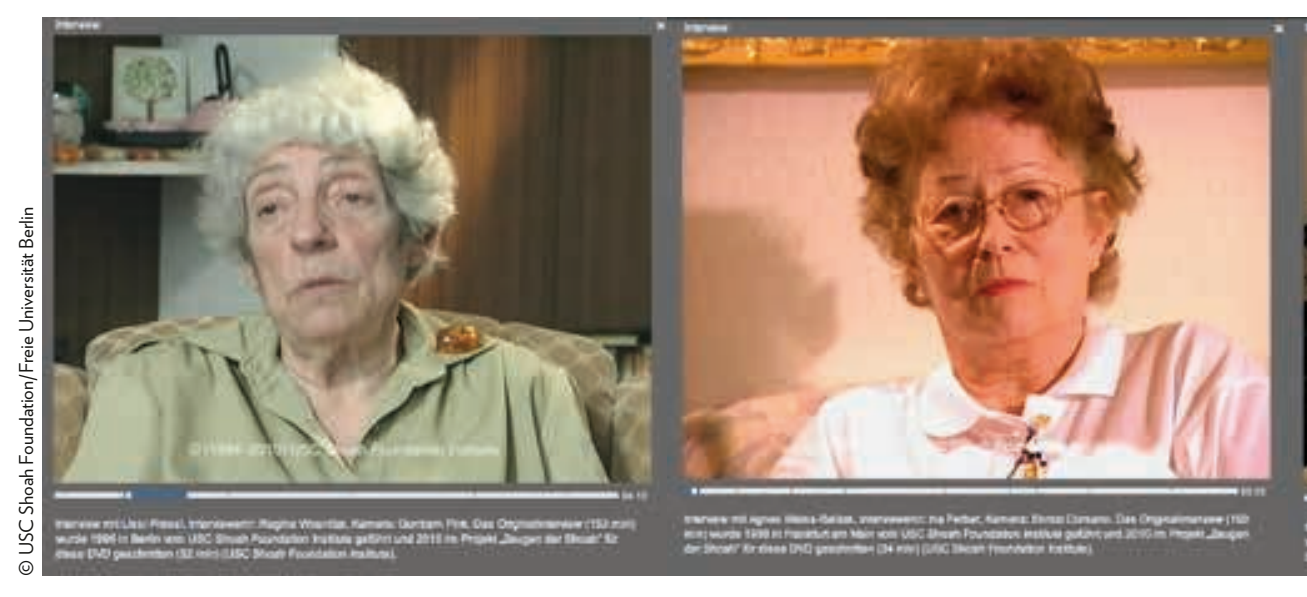

The faces of these three persons from the educational series mark the triumph over the Nazis' attempt to "to render the Jew faceless", even though they may reveal traces of the "progression in this mutilation of the face [of having been drained off life and losing their animation to death], from shame to sorrow to terror to emptiness" (Patterson 2006, 50-51). My article aims to understand how the new generation of German youths respond to these "faces".

\section{EMOTIONS AND EMPATHY IN GERMAN HISTORY EDUCATION}

The very personal stories captured by the interviews with the "witnesses of the Shoah" form the core of the educational medium in question. As such, the designers of the learning software consider the focus on empathy and emotions as a crucial aspect of Holocaust education. In her study of survivor testimonies, Brüning explains that these accounts are used in history lessons with a specific aim:

[T]he main point is to train viewers to agree to enter into a type of "communication process" with the story-teller, thereby teaching them how to change or take on different perspectives and how to experience "otherness" (Alterität). (Brüning 2013, 147)

Emotions, and particularly empathy as "emotional practice" (Brauer 2013, 75), can be understood as the vehicle for enabling such a "communication process".

Traditionally, however, German history didactics has concerns with emotions coming into play. While it is generally agreed that emotions shape consciousness, perceptions and memory (Brauer \& Lücke 2013, 15-19), German scholars are skeptical about their use for the mediation of historical content in the light of their nation's trak record of indoctrinatingyoung people. In the context of an exhibition

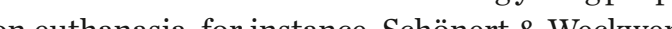
on euthanasia, for instance, Schönert \& Weckwerth $(2011,289)$ reflect on current debates about the effectiveness ofblending in "emotional impulses into the rational,
- Screen shots of the h survivo Balázs and Jack Bass. They were randomly selecte fon the nine Jewish is intended to bche Bildung (Federal Centre for Political Education) in Bonn and consists of four DVDs with the themes "Fleeing", "Surviving", "Resisting" and "Living on". Each DVD contains three video interviews that were first recorded between 1994 and 1999 as part of the VHA (Liepach 2015; Barricelli, Brauer \& Wein 2009). extensive learning software package as part of the series, based on twelve interviews selected from the overall archive of 52,000. The package consists of the personal accounts of the witnesses, shortened from about two hours to thirty minutes each In addition, a wide array of multimedial materials (primary and secondary sources in all imaginable formats) are provided for the solving of complex work assignments. 
informative educational work". Can visitors get emotionally overwhelmed to such a degree that they are unable to "process" (verarbeiten) factual information? There is indeed a belief that emotions "interfere with" (i.e. cancel out or are detrimenta to) the ability to take up historical "facts" cognitively and rationally, and that they have potentially manipulative qualities. The problem can also be partially related to the typical historicist focus on "facts" that has strongly influenced German history didactics. Whereas psychologists interpret "the textured speech and silences" in survivors' testimonies as attempts to communicate resistace and survival (Dor 181), historing (Dor Laub quoted in Simon \& Eppert 1997, 181), historians consider these emotionally charged moments inconsistent with the methodological and interpretative dictate of their discourse community. As a consequence, and unlike their Anglo-American colleagues, German history educators are reluctant to adopt a moral and empathy-related perspective (Brauer 2013, 81). It is not surprising then, as noted by Platt $(2016,182)$, that even after twenty years of interdisciplinary research about autobiographical survivor accounts, political and moral aspects of story-telling have received little attention by the German scientific community.

Many German schools ${ }^{2}$ nevertheless expect their students to develop an ability to make judgements (Urteilskompetenz) regarding Holocaust remembrance and "questions about guilt and responsibility of Germans for the National Socialist "questis (Al 2013,85). crimes" (Alavi 2013, 85). In order to educate young people in this sense, Hasber $(2013,63)$ rightly believes that "moral assessment and emotional access are just as fundamental as the rational appropriation of history". The DVD series Zeugen der Shoah explicitly addresses the topic, inviting pupils to reflect on the value of trauma in the life-stories, and on the relation to "factual" history. Hasberg $(2013,65)$ points to the lack of theoretical considerations and empirical research in this area. The current study aims to make such a timely contribution.

\section{SAMPLE AND METHOD}

My study was set out to assess the reception of the DVD-series Zeugen der Shoah in a German high school. It was carried out in a small German town of about Shoah in a German high school. It was carried out in a small German town of about 38,000 inhabitants with a population density of 240 persons per $\mathrm{km}^{2}$. Data was collected by ethnographic means. My fieldwork consisted of participant observation, during which I adopted an attitude of "involved detachment" (Moeran 2009) to describe the behaviour and beliefs of the pupils in the setting of the classroom. In addition to observation, ethnography also includes research methods such as interviews with teachers and pupils, text analysis, and questionnaires (Moeran 2009, 153; Walford 2008, 8). The participating teacher suggested that we run the project with the pupils in his Zusatzkurs, or supplementary course. Such a course makes an ideal context for the study because it is not based on centrally administered, final survivors when he was a teenager. He described the students of his Zusatzkurs as those who have less historical knowledge than the students of the centrally examined course and as those who prefer to work with concrete examples.

The teacher allowed the pupils to choose which video interviews to watch and later assigned some tasks from the software package to groups of two to three members. The class of 23 students worked for eight weeks with the materials, with three 45-minute lessons each week. My role was that of participant observant and I was not involved with education a asessment or pedagogical tasks. Before the eight not in week period $\mathrm{I}$ asked students to fill in a anout their opinions on the topic of week period they reflected on their experiences with the video interviews. Both mini surveys consisted largely of open-ended questions and served as tools for contextualizing the responses in the overall reception study. In addition, I conducted two focus group interviews with student volunteers in order to better understand their views and reflections. The interviews were not conducted to evaluate academic performance.

Of the 23 pupils that followed the course, 10 were male and 13 female, with ages ranging between 17 and 18,5 years. In the mini-survey preceding the viewings, most of them expressed a ken interest in the topic of the Holocaust. They had quesof then tions about factual data (e.g. the number of victims), the complicity of German civil society (e.g. "whether Germans really knew about everything") and lessons for the future (e.g. "how can something like this be prevented?"). Moreover, they showed empathy (e.g. "what was everyday life like in the concentration camps?"), and a sense of inconceivability about the crimes (e.g. "how could it come that far?"). All 23 pupils completed the post-viewing survey, while 15 were prepared to participate in a focus group interview after the project. Two separate focus group discussions were conducted with 8 ( 3 female, 5 male) and 7 (6 female, 1 male) pupils respectively, on two different days. The interviews were recorded with an audio device and transcribed in full. Both the transcripts a Both the transts and the written answers from the short surveys were coded with the qualitative research technique used for grounded theory generation, consisting of constant comparison analysis (Glaser \& Strauss, 1967). This means that the transcribed interviews were coded using "sensitizing concepts" (Kelle \& Kluge 2010) based on my theoretical pre-knowledge of the research field (deduction).Concepts included empathy, trauma, emotion reation, video-medium, tran a, en the constant comparison process, the pupils'

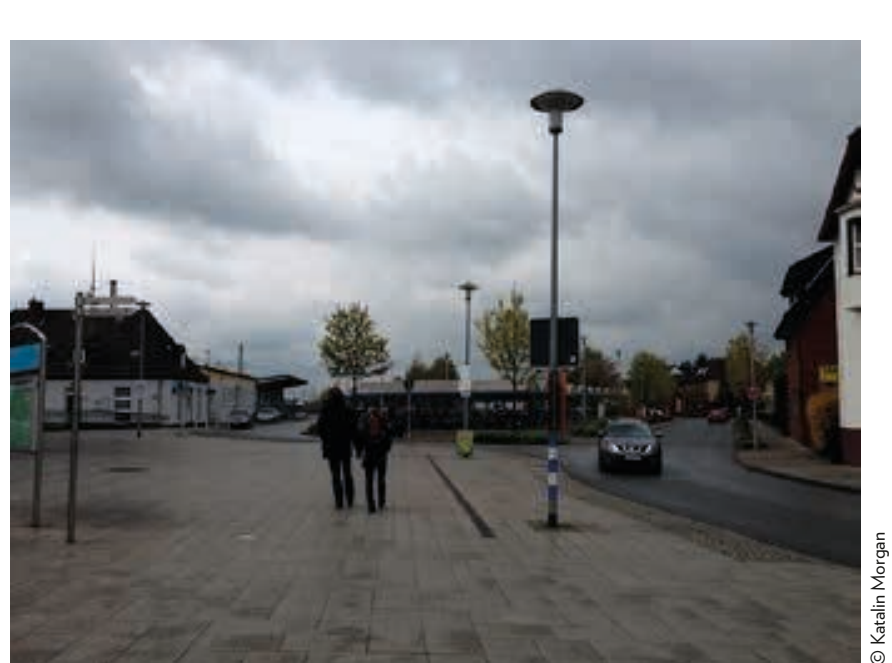
examinations (Abitur) contents according to his own choosing. The teacher's interest in the Shoah was 
answers were then examined for regularities and patterns (Cronin-Jones 1991, 236) allowing me to identify larger themes (induction), such as different forms of empathy with the victims, various emotional and cognitive ways of responding to the materials, the significance of the video medium, or relevance to today's socio-political problems.

In this article I focus on two questions specifically, one from the focus groups, and the other from the post-project short survey. The focus group question was: "What are your general, spontaneous impressions of the interviews with the witnesses, are your and did they addressyoupersonally? I I would code under the category "emotional reception", which was later refined and extended following unanticipated elements in the pupils' answers. The corresponding openended question in the survey was: "How would you sum up your thoughts and feeling about the work with the Zeugen der Shoah DVDs?" Both data, from the focus groups and the mini survey, were compared and combined in the following discussion.

\section{FINDINGS AND DISCUSSION}

\section{Emotional reception vs. (previous) knowledge}

Answering the focus group question about their impressions of the witness interviews, two students claimed they had a fairly good factual knowledge about what happened - some were introduced to the subject by their grandparents. Nonetheless, "to experience it so personally and to be shown so clearly what the emotions are of [the witnesses]", was new to them. When analyzing the responses to the mini survey, I found one male respondent confirming:

The DVDs have given me new insight into the subject matter. I was able to develop a much closer relationship to the Nazi era through the video interviews, and at times I got to know the topic from an even worse angle.

A similar statement appeared in a female respondent's answer, where she indicates that she "found the videos very impressive (beeindruckend $)^{3}$. Even if you knew the contents before, you have not yet been addressed by the affected people." The emotionality was further related to a sense of incomprehensibility:

The DVDs were partly very touching and emotional. The stories of the witnesses moved and touched me. I still find it unbelievable what kind of misery and suffering these people had to experience back then. The interviews allowed for a better insight and a better understanding of the situation at the time, but it remains very difficult to understand what really happened.

Many respondents regard "knowledge" as factual, objective and informative, and distinct from "feelings", as shown by the following reaction
I was already familiar with much of the information because I already had a lot of background knowledge. In addition to my knowledge, the project clarified the feelings of the witnesses for me, something that I was not aware of in this way before.

Emotions count as "awareness" but not as knowledge. Another student stated: "It was interesting to see personal experiences and impressions, however, there was not much new in terms of knowledge." Or: "For me, the subjective thoughts and feeling and the individua ways ofliving at that time were new, but my knowledge about the and thend time was not increased. One respondent in the focus group interviews preferred the "factual" nature of textbooks. However, he did not consider the apparent "non-factuality" of the victims' personal accounts as a reason to qualify them as "worthless". Yet not all respondents made the distinction between emotion and knowledge. Some described the video interviews as "expressly educational" despite the detailed and repeated previous engagement with the topic. For them, the personal narratives also contributed to new or alternative forms of "knowing":

The DVDs are very gripping. The personal interviews have shown me the fate of individual victims, which gave one another kind of impression. It was very informative to see the perspective of the witnesses on this historical period.

The medium of the video interviews (visibility and audibility combined) played an important role, as it appears: "One knows so much about this time, but some of the stories shocked me because you could see the person who lived through all these things." There were also exceptions, however: "In the end, hardly any feelings, some sympathy maybe, but I once again realized that I am really quite well informed." Pupils were generally able to relate the breaks and silences in the stories to the experience of trauma. This in itself can be regarded as a form of knowledge, if knowledge is defined in broader terms. Indeed, Selander's (2007) work on educational media demonstrates that learning implies an understanding of different modes of communication (e.g textur tial and visual), including any emotiont content that may be conveyed in this manner.

\section{A desire to imagine}

The materials on the DVDs differed significantly from those the respondents were familiar with from their textbooks. Seeing a person who is "there" was found to be "impressive" because "reading history is different from seeing a fate on someone's face". Beyond the factual content of the account, then, the survivor's emotions triggers in the viewer a desire to imagine what happened: "Well, it wasn't a case of watching the video and then thinking 'ok it was like that' In any case I was really touched" Many of the respondents felt empathy and were encouraged to "ime che touche" [to oneself in [the witness'] situation", even though, as one pupil describesit, "the power
of imagination was not sufficient for me to put myself in their shoes". 
Nevertheless, watching witnesses tell their personal stories at least helped students to imagine some of the reality that textbooks usually describe by abstract numbers. As one of the respondents indicates: "If you imagine that there are thousands, well, hundreds of thousands of these individual fates, that is not a hundred thousand, but one, plus one, plus one, plus one.” Or:

The personal interviews with individual persons have ensured that one does not only have (the NS but that there are alsopersont names and faces to it.

It seems as if the medium of the video interview, where the viewer is confronted with the face and voice of the witness, forced the students to at least try to imagine. The exercise became more difficult as the interviews progressed. Each interview would start with the witness telling his or her family story and instances of discrimination - where things are still "conceivable" - but in the end they would broach the subject of their family's cold blooded murder. Here we are at the limits of the imaginable.

\section{Transfer of emotions}

Pupils expressed compassion for the victims ("you feel extremely sorry for them"), but also respect and admiration, as they were impressed by the painful testimonies or by the fact that the survivors found ways of recording their experiences at the time, for example by creating works of art in a concentration camp. Interviewees described their emotional responses to the stories in the following way: "interesting though shocking"; "you had to swallow because it was something that you had never heard before and because it was quite cruel in some cases"; "touching"; "moving"; "poignant".

Overall, the emotional investment of the survivors was said to be "infectious": "TThe witnes] started crying later in the interview, which really affected me at

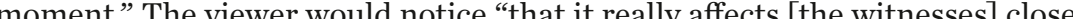
The body languge of the story-tellers clearly reflected their feelings, according one student: "You can se how uncomfortable they feet at times" The result is emotiont. "You can see how uncomfortable they feel at times." The result is an emotional transmission: the victim's emotional distress triggers a similar response in the tertiary witness. As one pupil puts it:

It is always something very different to see the witnesses tell their stories in person. In some places of the narratives one gets a little unsettled emotionally (bekommt man schon etwas beunruhigende Gefühle) because the situation gets closer.

In some cases, the respondents' feelings were short-lived, because through the repeated covering of the topic, "one has learned to deal with it". For others, the interview had a more lasting effect, which continued beyond the history lesson into the subsequent lesson, the content of which served as a welcome diversion. One of the respondents found that talking to her classmate about the interviews gave her a sense of relief: "I told her a lot about the interview that I had seen, I just chatted to her about what happened to the person, and that I had felt quite depressed by it." The discussions in the class or among the respondents were helpful and would even "stimulate you to think further". Another respondent also described how emotional transfer triggers reflection:

If you get the personal descriptions, it takes a hold of you a little bit more, so to speak to hear what really happened then, and because of that you start to think about it more deeply.

This confirms the idea that emotions are a central category for understanding the way young people appropriate the history of the Shoah.

\section{Indignation at the lack of resistance in German society}

Towards the perpetrators, pupils experienced complex emotions, ranging from anger to hatred and incomprehensibility: "I cannot understand people who have carried out such deeds, because one cannot imagine such acts", one respondent carried out such deeds, because one cannot imagine such acts", one respondent states. Some find it hard to acknowledge "how sick humanity is", and to see "how fast this can happen, that people are influenced like that". Others wonder how it was possible that so many Germans apparently became bystanders and submitted to the Nazi dictatorship unquestioningly,

[...] that they blindly followed all the rules and directly believed that the Jews were something worse and that they simply applied it to their own circle of friends. And that they did not personally somehow resist or rebel against it.

The alignment of many Germans with the Nazi's anti-Jewish policy is generally connected to centuries-old anti-Semitic ideas in Europe, but the students did not seem to be aware of this. Their teacher confirmed that antisemitism is not, or only very marginally, a topic in history class.

It is often assumed that anti-Semitic attitudes are automatically reduced if youths are made aware of discrimination against homeless, dark-skinned and disabled people (Matussek 2016, Kindle location 3269). However, a study commissioned by the German government has shown that there is a need to treat antisemitism separately, since it constitutes:

[...] a unique and specific phenomenon whose explosiveness cannot be grasped if it is [.] contism sministerium des Innern 2011, 146). 
Indeed, the students had very definite political views on the treatment of refugees and made undifferentiated and generalized connections between their fate and those of "the Jews" without perceiving the differences between the two (see Morgan 2017; Schwarz-Friesel \& Friesel 2012). As a consequence, they did not have the tools to understand the role of anti-Semitism in the behaviour of Germans during the Nazi era.

\section{CONCLUSION}

The DVDs were no doubt a new way for the pupils to learn about the Shoah and it allowed them to literally see and feel what the impact of the events was on the persons that had lived through it. My analysis has shown that emotions help to engage students in a more direct and personal way. Through seeing and hearing the story as told by the survivors, they develop an intimate and for them quite unique connection to history. Unlike the abstract numbers in their textbooks, witness interviews confront them with faces, gestures, body language and vocal intonations that trigger emotional transfer. Although their power of imagination was stretched beyond its limit respondents understood on an emotional or empathetic level that a purely cognitive processing of the contents of witnesses' stories would not allow them to perceive the trauma nor understand the gravity of the events. In the pupils descriptions of their emotional responses could be interpreted as the necessary temporary cognitive "blinding" required for really "seeing" the sorrow in the storie told by the witnesses (Liebsch 2016, 59). Emotional transfer indeed encourages reflection and questioning, as some pupils asserted that the witnesses remained with them after the class had ended. These findings confirm Eusterschulte's argumen $(2016,85)$ that the voices of the survivors, by the virtue of the fact that they are heard and do not remain repressed or ignored, serve a future-orientated political purpose.

Displaying empathy or making an emotional connection with the survivors does not necessarily lead to a full understanding of the complex and horrific reality of the Shoah. Other types of knowledge, such as the teaching of the history of anti-Semat the time or to recogize the duger of ever-present Jew hat Ged toly. The emains that emotions offer a fruitful new way of exploing the topic, and the is no reason to "fer" sus on an is ignorance, indifference, silencing, untruth and distortion.

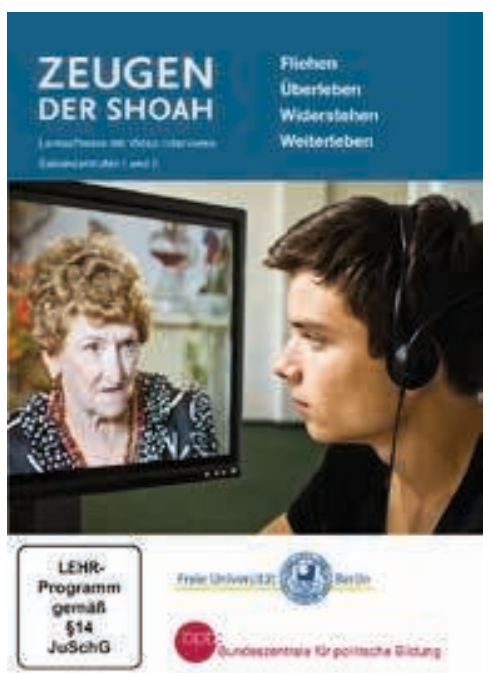

WORKS CITED

- Alavi, Bettina, "Herausforderungen an
eine "Erziehung nach Auschwitz" in der multikuturellen Gesellschaff', in Hanns-Fred
Rathenow Birgit Wenzel \& Norbert H. Weber Rathenow, Birgit Wenzel \& N Norbert H. We
(ds.), Handbuch Nationalsozialismus und Holocaust, Schwalbach am Taunus, 2013.
H9-94.

- Barricelli, Michele, Juliane Brauer \&
Dorothee Wein, Zeugen der Shoaah Historisches Lernen mit lebensgesschichtiche Videointerviews. Das Visual History Archive des Shoah Foundation institute
in der schulischen Bildung'. Medaon 5 , 2009. http://www.medaon.de/de/artikel/ zeugen-der-shoah-historisches-lernen-mitvisual-history-archive-des-shoah-foundationinstitute-in-der-schulischen-bildung/ (accessed 22 December 2017 ). - Brauer, Juliane, Empathie und historische
Alteritattserfahrungen', in Juliane Brauer \& und historisches Lernen, Geschichtssdidaktische und geschichtskulturelle Perspektiven,

- Brauer, Julian \& Martin Lücke (eds.), Emotionen, Geschichte und historisches
Lernen. Geschichssdidaktische und geschichtskultw
V\&R Unipress.

- Brüning, Christina, 'Historisches Lernen mit videographierten Zeitzeug-inneninterviews heterogenen Lerngruppen', Zeitschrift für
Genozidforschung 14(1-2), 2013, 138-167.

Bundesministerium des Innern,
Antisemitismus in Deutschland. Erscheinungsformen, Bedingungen,
Prä̀nentionsansätza. Bericht des unabhängigen Expertenkreises Antisemitismus, 2011.
htps:/www.bmi.bund.de/SharedDocs/ https:///www.bmi.bund.de/SharedDocs/
downloads/DE/themen/gesellschaftdownloads/DE/themen/gesellschaft-
integration/lexpertenkreis-antisemitismus/ bericht-1.pdr? - blob=bublica
(accessed 21 December 2017)

Cronin-Jones, Linda, 'Science teacher
beliefs and their influence on curriculum implementation: Two cases studies's, Jum rural
of Research in Science Teaching 28(3), 1991, 235-250.

- Eusterschulte, Anne, 'Leibliches Hören. in Sonja Knopp, Sebastian Schulze \& Anne Eusterschulte (eds.), Videographierte
Zeugenschaft. Ein interdisziplinärer Dialog,
Weilerwwist: Velbrück Wissenschaft, 2016, 71-99.

Glaser, Barney \& Anselm L. Strauss, The Discovery of Grounded Theory: Strategies for
Qualititive Research, Chicago, LL: Adline, 1967 - Hasberg, Wolfgang, Zum systematichen Or Lücke (eds.), Emotionen, Geschichte und historisches Lernen. Geschichtsdidaktische und
geschichtskulturelle Perspektiven, Göttingen, Veschichtskulturelle Perspel.

Kelle, Udo \& Susann Kluge, Vom Einzelfall zum Typus: Fallvergleich und Fallkontrastierung
in der qualitativen Sozialforschung, Wiesbade VS Verlag fur Sozil Wsenschaften, 20. - Liebsch, Burkhard, "Unsichtbare Gewalt:

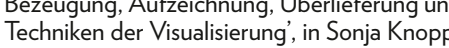
Sebastian Schulze \& Anne Eusterschulte (eds.), Videographierte Zeugenschaft. Ein
interdisziplinärer Dialog Weils interdisziplinärer Dialog, We

Liepach, Martin, Zeitzeugenvideos an Perspektivwechsel, Erinnerungssdiskurs und Kompetenzerwerb, in Claudia Müller, Patricic
Ostermann \& Karl-Siegbert Rehberg (eds) Ostermann \& Karl-Siegbert Rehberg (eds),
Die Shoah in Geschichte und Erinnerung. Perspektiven medialer Vermittlung in Italien und Deutschl/ar
$2015,157-168$
Matussek, Carmen, Irrael, mein Freund:
Stimmen der Versöhnung aus der ista: Welt, Holzgerlingen: SCM-Verlag, 2016. - Moeran, Brian, 'From Participant Observation
to Observant Particication' in Sierk Ybemita to Observant Participation', in Sierk Ybema,
Dvora Yanow, Harry Wels \& Frans Kamsteeg (eds.), Organizational Ethnography: Studying the Complexities of Everyday Life, Londo

Morgan, Katalin, II it possible to understand
the Holocaust? Insights from some Gerate school contexts, Holocaust Studies 23(4) 2017, 441-463. - Patterson, David, Wresting with the Angel.
Towards a Jewish Understanding of the Nazi
Assault on the Name, St Paul, MN: Paragon House, 2006.

Platt, Kristin, Narrative und traumatische \& Anne Eusterschulte (eds.). Videographierte Zeugenschafft. Ein interdisziplinärar Dialog,

Schönert, Volker \& Susanne Weckwerth, (ed.), Erschrecken - Mitgefühl - Distanz. Empirische Befunde über Schülerinnen
und Schüler in Gedenkstätten und zeitgeschichtlichen Ausstellungen, Leipzig:
Leipziger Universitattsverlag, 2011, 283-305.

- Schwarz-Friesel, Monika \& Evyatar Friesel, "Gestern die Juden, heute die Muslime...?" Gon den Gefahren falscher Analogien, in Kopke \& Michael Spieker (eds.), Illamophob und Antisemitismus - ein umstrittener - Selander, Staffan, 'Designs of democracy Mike Horsely \& James McCall (eds.).
Mes Peace, Democratization and Reconciliation

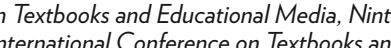
Educational Media, IARTEM, Norway and Australia, 2007, 11-20.

Simon, Roger I. \& Claudia Eppert, Remembering Obligation: Pedagogy and Education 22(2), 1997, 175-191.

- Walford, Geoffrey, How to do Educational Ethnog.
2008 . 